\title{
Communication
}

[Comunicação]

\section{Total mercury in sharks along the southern Brazilian Coast}

[Mercúrio total em tubarões capturados na costa brasileira]

\author{
E.T. Mársico ${ }^{1}$, M.E.S. Machado ${ }^{2}$, M. Knoff ${ }^{3}$, S.C. São Clemente ${ }^{1}$ \\ ${ }^{1}$ Faculdade de Veterinária - UFF \\ Rua Vital Brazil Filho, 64 \\ 24230-340 - Niterói, RJ \\ ${ }^{2}$ Ministério da Agricultura Pecuária e Abastecimento - Brasília, DF \\ ${ }^{3}$ Fundação Oswaldo Cruz - Rio de Janeiro, RJ
}

Since the discovery that Minamata disease was originated from the consumption of fish contaminated with organic mercury from industrial pollution, the study of poisoning by mercury has received wide attention with an increased number of studies on fish caught for human consumption. Top predators species, such as sharks, have been pointed out as indicator of heavy metals in the environment, and they frequently contain the highest concentrations, even in unpolluted areas. Heavy metals concentrations in sharks have been widely studied in several areas, but very little information is available on species from the Southern Brazilian coast. Various regulatory agencies have set limits on mercury levels in fish and shellfish, to attempt to safeguard public health. Mercury concentrations above the regulatory limits have been observed in several cases. According to Andersen and Depledge (1997), the limit of $0.5 \mu \mathrm{g} \cdot \mathrm{g}^{-1}$ by wet wt, recommended for mercury in seafood by WHO (Environmental..., 1976), is frequently exceeded in long-lived species and/or in species from high trophic levels. It is generally accepted that consumption of fish is the most significant route of human exposure to environmental mercury (Fujiki and Tajima, 1992). Mercury in fish is found almost totally as methylmercury and the toxic effects of its ingestion can result in serious and permanent damage to the central nervous systems and also can pass through the placental barrier, endangering the human foetus (Galli and
Restani, 1993). Due to its reactivity with sulfurcontaining amino acids, mercury is stored in fish protein matrices, rather than in fatty tissues (Harris et al., 2003). Mercury acquisition, accumulation, and biomagnification in fish are associated with both $\mathrm{Hg}$ chemical form and fish feeding-behavior (Hoyle and Handy, 2005) and carnivorous fish at the top of the chain acquire large amounts of Methyl-mercury that are bioaccumulated as a function of fish size (Barbosa et al., 2003). The primary purpose of this paper is to supply data on mercury accumulation in three shark species inhabiting the Southern Brazilian coast, considering variation of mercury concentration among individuals and the relationship between mercury content and size of the fish.

Samples of 39 sharks from three species were collected and captured about 50m deep, 190 miles of the coast of Santa Catarina State $\left(27^{\circ} 08^{\prime} \mathrm{S}-28^{\circ} 38^{\prime} \mathrm{S}\right.$ and $\left.45^{\circ} 30^{\prime} \mathrm{W}-46^{\circ} 53^{\prime} \mathrm{W}\right)$ by professional fishermen of Kiyomã tuna fish boat. Species and total length of each shark were recorded. On board, fish muscle samples were taken about $2.0 \mathrm{~cm}$ below the epidermis, weighted, measured and stored in plastic bags, maintained cool onto ice and then frozen at $20^{\circ} \mathrm{C}$, until analysis. All glassware used was acid-washed, soaked in a $3 \% \mathrm{HNO}_{3}$ solution for $24 \mathrm{~h}$, and rinsed with distilled water. To correct for possible mercury contamination of reagents, blanks were determined with each set of samples

Recebido em 18 de abril de 2007 
and corrections were made when necessary. Blank samples were treated as for the tissues. Mercury concentrations were determined in two replicate samples of each tissue, both replicates being analyzed in duplicate. Caudal tissue samples were partially thawed, any skin removed, and the residual tissue homogenized to a fine paste. Four grams of this homogenized edible muscle tissue (flesh) was used. Mercury concentrations were determined by cold vapor atomic absorption spectrometry using a Bacharah Coleman, MAS 50B instrument. The analytical procedure followed the method reported by Deitz et al. (1973). Thus, $4 \mathrm{~g}$ of tissue, in glass vials containing $0.040 \mathrm{mg}$ of vanadium pentoxide, were acid digested with $15 \mathrm{ml} 65 \% \mathrm{HNO}_{3}$. Vials were then tightly capped and heated at $140^{\circ} \mathrm{C}$ for $20 \mathrm{~min}$, in order to decompose the tissues without breaking down the covalent bond Table 1 . Total mercury $(\mathrm{Hg})$ concentrations $\left(\mu \mathrm{g} . \mathrm{g}^{-1}\right)$ in the muscle tissues of three species of sharks from Southern Brazilian coast

\begin{tabular}{lcccc}
\multicolumn{1}{c}{ Species } & \multirow{n}{*}{} & \multicolumn{2}{c}{ Hg total } & \multirow{2}{*}{ Range } \\
\cline { 3 - 5 } & & Mean & SD & $0.012-1.150$ \\
Prionace glauca & 30 & 0.398 & 0.290 & $0.120-0.691$ \\
Isurus oxyrhinchus & 4 & 0.384 & 0.246 & $0.015-0.704$ \\
Sphyrna zygaena & 5 & 0.443 & 0.299 & \\
\hline
\end{tabular}

SD: standard deviation

Several authors have reported mercury concentration associated with body size in marine fish (Ueda and Takeda, 1983; Marcovecchio et al., 1988). Similarly, it was observed a statistically significant positive correlation between mercury contents in $P$. glauca muscle tissues and fish size $(\mathrm{r}=0.62$, $\mathrm{P}<0.001)$. Total mercury concentration observed here were in agreement with the range of values reported in a previous investigation on sharks by Lyle (1984), but were lower than the levels reported by Boush and Thieleke (1983) and Caputi et al. (1979) for sharks from the SouthWestern Pacific Ocean. The mercury concentrations measured in muscle tissues of sharks showed high variation. Such variability reflects the cumulative process of mercury uptake in fish and the interactions of biotic parameters such sex, age, size, and growth rate, as described by Hornung et al. (1993) who detected high mercury levels (up to $8.76 \mu \mathrm{g} . \mathrm{g}^{-1}$ wet wt) in deep-water sharks from the Mediterranean. High concentrations of mercury in marine fish are most likely to be observed in coastal areas where local discharges of mercury- between carbon and mercury. Subsequently, $30 \mathrm{ml}$ conc. $\mathrm{H}_{2} \mathrm{SO}_{4}$ were added and the medium heated again at $140^{\circ} \mathrm{C}$ for $20 \mathrm{~m}$. Inorganic mercury $\left(\mathrm{Hg}^{2+}\right)$ was then selectively reduced to elemental mercury by $1 \%(\mathrm{w} / \mathrm{v}) \mathrm{SnCL}_{2}$ in $\mathrm{HCl}$ in a reaction chamber. The elemental mercury was swept out of the solution under gentle air flow, and light absorption was finally measured at 253.7nm. Comparison of mercury concentration in the three shark species were performed by Kruskal-Wallis test. Relationship between mercury concentration and fork length were tested by correlation analysis.

Mean values of total mercury concentration, standard deviations and ranges are given in Table 1 for three species of shark. Means ranged from 0.384 to 0.443 and maximum individual concentration was $1.150 \mu \mathrm{g} \cdot \mathrm{g}^{-1}$. 
1976). In sharks, which contain naturally high mercury concentration of mercury, it may be necessary restricted the consumption. Although Holden (1973) states that restriction of the consumption of fish containing up to $1 \mathrm{mg} \cdot \mathrm{kg}^{-1}$ of mercury is an unnecessarily cautions, heavy consumption of sharks from areas where local pollution has resulted in high levels well above 1 $\mathrm{mg} . \mathrm{kg}^{-1}$ of fish should be discouraged. In view of the importance of marine fish as a protein source, it is urgent that an official decision be reached, by an international regulatory agency, on the maximum mercury content permissible in fish for human consumption. The establishment of such limit is a need to allow estimation of the total mercury exposure of Brazilian people through the consumption of seafood. The high level of mercury accumulation in sharks from Southern Brazilian coast is by no means unexpected since they are the top predators in their corresponding trophic chain.

Keywords: shark, mercury, bioaccumulation

\section{RESUMO}

Pesquisou-se a concentração de mercúrio total na porção muscular de 39 exemplares de tubarões de três diferentes espécies Prionace glauca, Isurus oxyrhynchus, Sphyrna zygaena, capturados na costa sul do Brasil, Santa Catarina. O teor de mercúrio foi determinado por espectrofotometria de absorção atômica por vapor frio. Observou-se ampla variação na concentração de mercúrio total com valor individual máximo excedendo o limite estabelecido pela legislação brasileira, de $1.0 \mu \mathrm{g}_{\mathrm{g}} \mathrm{g}^{-1} \mathrm{em}$ um exemplar fêmea de P. glauca. Nessa espécie, a concentração de Hg-total aumentou proporcionalmente ao comprimento total $(r=0,62 ; P<0,0001)$. Não foi evidenciada diferença estatisticamente significativa entre exemplares fêmeas e machos.

Palavras-chave: tubarão, mercúrio, bioacumulação

\section{ACKNOWLEDGMENTS}

The authors are greatly indebted to Drs. Alberto Ferreira Amorin and Carlos Arfelli from the Instituto de Pesca, Santos, State of São Paulo, for the identification of fish and to the fisherman of the fishing boat Kyomã from Santos, for the help during capture of hosts. We are also grateful to Dr. Roberto Magalhães, for the idiom revision. This research was partially financed by the Conselho Nacional de Pesquisa (CNPq) Brazil.

\section{REFERENCES}

ANDERSEN, J.L.; DEPLEDGE, M.H. A survey of total mercury and methylmercury in edible fish and invertebrates from Azorean waters. Marine Environ. Res., v.44, p.331-350, 1997.

BARBOSA, A.C.; SOUZA, J.; DÓREA, J.G. et al. Mercury biomagnification in a tropical black water, Rio Negro, Brazil. Arch. Environ. Contam. Toxicol., v.45, p.235-246, 2003.

BOUSH, G.M.; THIELEKE, J.R. Mercury content in sharks. Bull. Environ. Contam. Toxicol., v.30, p.284-290, 1983.
CAPUTI, N.; EDMONDS, J.S.; HEALD, D.I. Mercury content of shark from South-Western Australian Waters. Mar. Pollu. Bull., v.10, p.337-340, 1979.

CROSS, F.A.; HARDY, L.H.; JONES, N.Y. et al. Relation between total body weight and concentrations of manganese, iron, copper, zinc, and mercury in white muscle of bluefish (Pomatomus saltatrix) and a bathyldemersal fish antimora rostrata. J. Fish. Res. Board Can., v.30, p.1287-1291, 1973.

DEITZ, F.D.; SELL, J.L.; BRISTOL, D. Metals and other elements - Rapid, sensitive method for determination of mercury in a variety of biological samples. J. Assoc. Anal. Chem., v.56, p.378-382, 1973.

ENVIRONMENTAL health criteria I. Genebra: WHO, 1976. 131p.

EVALUATION of certain food additives and contaminants $\mathrm{Hg}, \mathrm{Pb}$ and $\mathrm{Cd}$. $16^{\text {th }}$ Report of the Expert Committee on Food Additives. Roma: FAO/WHO, 1972. (Tech. Rep. Ser. No.505).

FRANCESCONI, K.A.; LENANTON, R.C.J. Mercury contamination in a semi-enclosed marine embayment: organic and inorganic 
mercury content of biota, and factors influencing mercury levels in fish. Mar. Environ. Res., v.33, p.189-212, 1992.

FUJIKI, M.; TAJIMA, S. The pollution of Minamata Bay by mercury. Water Sci. Technol., v.25, p.133-144, 1992.

GALLI, C.L.; RESTANI, P. Can methylmercury present in fish affect human health? Pharmacol. Res., v.27, p.115-127, 1993.

HARRIS, H.H.; PICKERING, I.J.; GEORGE, G.N. The chemical form of mercury in fish. Science, v.301, p.1203, 2003.

HOLDEN, A.V. Mercury in fish and shellfish. A review. J. Food Technol., v.8, p.1-25, 1973.

HORNUNG, H.; KROM, M.D.; COHEN, Y.; BERNHARD, M. Trace metals content in deepwater sharks from the Eastern Mediterranean Sea. Mar. Biol., v.115, p.331-338, 1993.

HOYLE, I.; HANDY, R.D. Dose-dependent inorganic mercury absorption by isolated perfused intestine of rainbow trout, Oncorhynchus mykiss, involves both amiloridesensitive and energy-dependent pathways. Aquat. Toxicol., v.72, p.147-159, 2005.
LUTEN, J.B.; BOUQUET, W.; RIEKWELBOOY, G. et al. Mercury in flounder, Platichthys flesus, cod, Gadus morhua, and perch, Perca fluviatilis in relation to their length and environment. Bull. Environ. Contam. Toxicol., v.38, p.318-323, 1987.

LYLE, J.M. Mercury concentrations in four carcharhinid and three hammerhead sharks from coastal waters of the northern territory. Austr. $J$. Freshwater Res., v.35, p.441-51, 1984.

MARCOVECCHIO, J.E.; MORENO, V.J.; PÉREZ. A. Determination of heavy metal concentration in biota of Bahía Blanca, Argentina. Sci. Total Environ., v.75, p.181-90, 1988.

UEDA, T.; TAKEDA. M. Mercury and Selenium in two species of sharks. Bull. Jpns. Soc. Scient. Fish., v.49, p.1731-1735, 1983.

WATLING, R.J.; WATLING, H.R.; STANTON, T.P. et al. The distribution and significance of toxic metals in sharks from the Natal Coast, South Africa. Water Sci. Technol., v.14, p.21-30, 1982. 